\title{
DATA AVAILABLE ONLINE AND ON CD-ROM
}

Database

INDSTAT2: UNIDO

Industrial Statistics Database at the 2-digit level of ISIC code (Revision 3)

\section{Description}

Long time series data for more than 170 countries/areas compiled on eight principal indicators (number of establishments, total employment, female employment, wages and salaries paid to employees, output, value added, gross fixed capital formation and index numbers of industrial production) starting from 1963 onwards. The data are arranged at the 2-digit level of ISIC (Revision 3) pertaining to the manufacturing sector, which comprises 23 manufacturing divisions.
INDSTAT4: UNIDO

Industrial Statistics Database at the 3- and 4-digit levels of ISIC code (Revision 3 \& 4)
Time series data for more than 140 (Revision 3)/100 (Revision 4) countries/areas on seven selected data items including number of establishments, total employment, female employment, wages and salaries paid to employees, output, value added and gross fixed capital formation. The data are arranged at the 3- and 4-digit levels of ISIC (Revision $3 \& 4$ ) pertaining to the manufacturing sector.
MINSTAT: UNIDO Mining \& Utilities Statistics Database at the 2- and 3-digit levels of ISIC code (Revision 3 \& 4)
Time series data for more than 110 (Revision 3)/90 (Revision 4) countries/areas on seven selected data items including number of establishments, total employment, female employment, wages and salaries paid to employees, output, value added and gross fixed capital formation. The data are arranged at the 2- and 3-digit levels of ISIC (Revision 3 \& 4) pertaining to the mining and utilities sectors.

Time series data for more than 120 (Revision 3)/100 (Revision 4) countries/ areas on output, imports, exports and apparent consumption (all in current United States dollars) at the 4-digit level of ISIC Revision $3 \& 4$.

Country data on GDP, MVA and population for various regions and groups of economies displayed at constant 2015 and at current United States dollars prices.

Country data on ranks and values of Competitive Industrial Performance (CIP) index and its component indicators.

Further details on above products may be obtained from:

Statistics Division

UNIDO

Email: stat@unido.org

Internet: http://www.unido.org/statistics 
UNIDO - 9781800886506 